\title{
PENGARUH MODEL PEMBELAJARAN KOOPERATIF TIPE STAD DENGAN METODE MNEMONIK TERHADAP HASIL BELAJAR SISWA KELAS X DI SMA MUHAMMADIYAH 1 SURABAYA
}

\author{
Marissa Yuliana', Wahyuni Suryaningtyas ${ }^{2}$, Shoffan Shoffa ${ }^{3}$ \\ Program Studi Pendidikan Matematika, FKIP UMSurabaya \\ Email: marissa.yuliana19@gmail.com
}

\begin{abstract}
ABSTRAK
Penelitian ini bertujuan untuk mengetahui ada tidaknya pengaruh positif dan signifikan dari model pembelajaran kooperatif tipe STAD dengan metode Mnemonik terhadap hasil belajar siswa kelas X SMA Muhammadiyah 1 Surabaya. Jenis penelitian yang dilakukan adalah penelitian kuantifatif. Penelitian ini dilaksanakan pada siswa kelas X di SMA Muhammadiyah 1 Surabaya. Desain yang digunakan dalam penelitian ini adalah Pretest-Posttest Control Group Design. Sampel dalam penelitian adalah kelas X-5 sebagai kelas eksperimen dan kelas X-3 sebagai kelas kontrol. Hasil penelitian menunjukkan bahwa: (1) Hasil nilai uji $t$ satu pihak, diperoleh posttest 1 dengan $t_{\text {tabel }}=2,00 \leq t_{\text {hitung }}=3,35$ dan posttest 2 dengan $t_{\text {tabel }}=2,00 \leq t_{\text {hitung }}=3,07$, maka $H_{1}$ diterima sehingga didapatkan hasil bahwa rata-rata skor tes akhir pada kelompok eksperimen lebih baik daripada rata-rata skor tes akhir pada kelompok kontrol. Dari hasil penelitian ini dapat disimpulkan bahwa model pembelajaran tipe STAD dengan metode mnemonik berpegaruh positif dan signifikan terhadap hasil belajar siswa, (2) Hasil presentase angket respon siswa diperoleh bahwa (pada pernyataan angket positif) 29,4\% siswa Sangat Setuju dan 61,3\% siswa Setuju dengan model pembelajaran tipe STAD dengan metode mnemonik pada pelajaran matematika dengan materi Trigonometri, ini berarti banyak siswa pada kelompok kelas eksperimen merespon baik terhadap model pembelajaran kooperatif tipe STAD dengan metode mnemonik dikelas.
\end{abstract}

Kata Kunci: hasil belajar, model pembelajaran Kooperatif tipe STAD, metode mnemonik

\begin{abstract}
This research aims to find out the significant and positive effect of STAD learning model using mnemonic method to learning outomes of students of of class X at SMA Muhammadiyah 1 Surabaya. This type of research is quantitative research. The research was conducted on students of class $X$ at SMA Muhammadiyah 1 Surabaya. The design used in this research was a pretestposttest control group design. Samples were class $X-5$ as the experimental class and class X-3 as the control class. The results show that: (1) The results of the t test values of the party is obtained posttest 1 with $t_{\text {table }}=2.00 \leq t_{\text {count }}=3.35$ and posttest 2 with $t_{\text {table }}=2.00 \leq t_{\text {count }}=3.07$, then $H_{1}$ is accepted so that it is gained the average score of the final test of the experimental group was better than the average score of the final test in the control group. From these results, it can be concluded that the STAD learning model using mnemonic method gives a positive and significant impact on student learning outcomes, (2) The percentage of student questionnaire responses shows with positive statement is "strongly agree" as much as $29.4 \%$ of students, while as much as $61.3 \%$ of students is "agree" with the implementation of STAD learning model using mnemonic method in math with Trigonometry topic, this means that many students in the experimental class group give positive responds to the STAD learning model using mnemonic method in the classroom.
\end{abstract}

Keywords: mnemonic method, learning outcomes, STAD learning model. 


\section{PENDAHULUAN}

Matematika merupakan suatu ilmu yang mendukung penguasaan ilmu pengetahuan dan teknologi. Melalui belajar matematika kemampuan berpikir logis dapat ditumbuhkan, juga kemampuan berpikir kritis dan kreatif dapat dilatihkan sehingga matematika dapat dikategorikan ilmu dasar. Rumus-rumus yang dipelajari dalam matematika memiliki peranan penting yang dapat diterapkan dalam kehidupan sehari hari. Oleh karena itu matematika dianggap sebagai dasar mempelajari ilmu pengetahuan. Maka diberikanlah matematika kepada semua peserta didik mulai jenjang pendidikan dasar sampai pendidikan menengah.

Pembelajaran matematika menjadi perhatian penting, karena matematika merupakan salah satu mata pelajaran pokok. Pembelajaran matematika disekolah juga diharapkan dapat mendukung kecakapan hidup (life-skill). Pelaksanaan pembelajaran tidak boleh sekedar guru memberikan materi kemudian siswa menerima tetapi guru dituntut harus lebih kreatif dengan perkembangan ilmu pengetahuan matematika.

Berdasarkan pengalaman yang penulis dapatkan pada waktu melaksanakan Program Pengalaman Lapangan (PPL) di sekolah guru masih menggunakan pendekatan konvensional dalam pembelajaran matematika dan saat pembelajaran berlangsung siswa kurang memperhatikan guru saat menerangkan pelajaran matematika. Dari hasil wawancara dengan guru matematika kelas X SMA Muhammadiyah 1 Surabaya saat ini pembelajaran disekolah tersebut masih berpusat pada guru sehingga menjadikan siswa kurang aktif dalam proses pembelajaran dan dari hasil wawancara dengan beberapa siswa kelas X SMA Muhammadiyah 1 Surabaya siswa merasa pelajaran matematika sangat membosankan dan siswa sangat kesulitan dalam menghafal berbagai rumus matematika.

Berdasarkan data observasi dari nilai UTS hasil belajar matematika siswa kelas X dengan kriteria ketuntasan minimal (KKM) yang telah ditentukan SMA Muhammadiyah 1 Surabaya yaitu 75. Di kelas X-1 dengan jumlah siswa 37 hanya 10 siswa (27\%) yang mencapai nilai Kriteria Ketuntasan Minimal (KKM) dan 27 
siswa (73\%) masih belum mencapai Kriteria Ketuntasan Minimal (KKM). Di kelas X-2 dengan jumlah siswa 35 hanya 12 siswa (34,3\%) yang mencapai nilai Kriteria Ketuntasan Minimal (KKM) dan 23 siswa (65,7\%) masih belum mencapai Kriteria Ketuntasan Minimal (KKM). Di kelas X-3 dengan jumlah siswa 31 hanya 10 siswa $(32,3 \%)$ yang mencapai nilai Kriteria Ketuntasan Minimal (KKM) dan 21 siswa (67,7\%) masih belum mencapai Kriteria Ketuntasan Minimal (KKM). Di kelas X-4 dengan jumlah siswa 31 hanya 11 siswa (35,3\%) yang mencapai nilai Kriteria Ketuntasan Minimal (KKM) dan 20 siswa (64,5\%) masih belum mencapai Kriteria Ketuntasan Minimal (KKM). Di kelas X-5 dengan jumlah siswa 31 hanya 9 siswa (29\%) yang mencapai nilai Kriteria Ketuntasan Minimal (KKM) dan 22 siswa (71\%) masih belum mencapai Kriteria Ketuntasan Minimal (KKM).

Dengan demikian dapat disimpulkan hasil UTS seluruh siswa kelas X SMA Muhammadiyah 1 dengan jumlah 165 siswa hanya 52 siswa $(31,5 \%)$ yang mencapai nilai Kriteria Ketuntasan Minimal (KKM) dan 113 siswa (68,5\%) masih belum mencapai Kriteria Ketuntasan Minimal (KKM). Dari hasil nilai UTS tersebut hasil belajar matematika siswa kelas X SMA Muhammadiyah masih tergolong rendah. Untuk itu peneliti memilih sekolah SMA Muhammadiyah 1 kelas X sebagai sekolah dan kelas penelitian.

Salah satu metode yang dipilih dalam penelitian ini adalah metode mnemonik. Metode ini dipilih untuk mempermudah siswa dalam menghafal rumus matematika seperti materi trigonometri. Metode mnemonik memiliki teknik yang bervariasi untuk menyelesaikan problem ingatan. Metode ini cukup mudah untuk diaplikasikan. Metode mnemonik bekerja mengikuti cara kerja otak, sehingga memungkinkan peserta didik mampu mendapatkan hasil yang maksimal. Menurut Stine (2003:86), metode mnemonik adalah kemampuan pikiran untuk mengasosiasikan kata-kata, gagasan atau ide dan gambaran. Informasi yang terkait di seputar elemen-elemen yang mudah diingat dan gambaran yang luar biasa dan tidak terlupakan.

Berdasarkan uraian di atas, peneliti tertarik untuk melakukan suatu penelitian dengan judul "Pengaruh Model Pembelajaran Kooperatif Tipe STAD 
Dengan Metode Mnemonik Terhadap Hasil Belajar Siswa Kelas X Di SMA Muhammadiyah 1 Surabaya"

Adapun tujuan penelitian ini adalah:

1. Mengetahui pengaruh metode mnemonik terhadap hasil belajar siswa kelas X-5 pada materi trigonometri di SMA Muhammadiyah 1 Surabaya.

2. Mengetahui respon siswa kelas kelas X-5 SMA Muhammadiyah 1 Surabaya pada penggunaan metode mnemonik pada materi trigonometri.

\section{METODE PENELITIAN}

Penelitian ini merupakan penelitian eksperimen dengan pendekatan kuantitatif. Penelitian ini berupaya mengetahui ada tidaknya pengaruh yang signifikan pada metode mnemonik terhadap hasil belajar siswa. Penelitian ini dilakukan pada dua kelas dalam satu sekolah dengan cara membandingkan dua kelas tersebut yaitu kelas eksperimen dan kelas kontrol. Pada kelas eksperimen diterapkan pembelajaran metode mnemonik sedangkan pada kelas kontrol menggunakan pembelajaran metode ceramah.

Desain yang digunakan dalam penelitian ini adalah True Eksperimental Design. Dalam desain ini, peneliti dapat mengontrol semua variabel luar yang mempengaruhi jalannya eksperimen. Salah satu dari True Eksperimental Design yaitu Pretest-Posttest Control Group Design. Desain yang dilakukan yakni dengan membandingkan kelompok yang diberikan perlakuan (X) melalui skor yang diperoleh dari pelaksanaan pretest $(\mathrm{O})$ dan posttest $(\mathrm{O})$. Tujuan melakukan eksperimen ini adalah mengetahui perbedaan yang signifikan antara hasil tes awal (pretest) dan tes akhir (posttest) pada kelas eksperimen dan kelas kontrol serta dari tes awal dan tes akhir tersebut terlihat ada pengaruh atau tidaknya perlakuan (treatment) yang telah diberikan.

Adapun desain penelitian yang digunakan dalam penelitian ini menurut Sugiyono (2011:159) adalah:

\begin{tabular}{|cccc|}
\hline & & Desain Penelitian & \\
Kelompok & Pretest & Perlakuan & Posttest \\
$\mathrm{R}$ & $O_{1}$ & $\mathrm{X}$ & $O_{2}$ \\
\hline
\end{tabular}




\begin{tabular}{|lll|}
\hline $\mathrm{R}$ & $O_{1}$ & $O_{2}$ \\
\hline
\end{tabular}

Keterangan:

$\mathrm{R}=$ kelas eksperimen dan kelas kontrol siswa SMA Muhammadiyah 1 Surabaya yang diambil secara random

$O_{1}=$ kedua kelas tersebut diobservasi dengan melakukan pemberian pretest untuk mengetahui hasil belajar awalnya.

$\mathrm{O}_{2}=$ kedua kelas tersebut diobservasi dengan melakukan pemberian posttest untuk mengetahui hasil belajar akhir.

$\mathrm{X}=$ treatment atau perlakuan. Kelompok atas sebagai kelas eksperimen yang diberikan treatment, yakni pembelajarannya dengan menggunakan metode mnemonik.

Tempat pelaksanaan penelitian ini adalah SMA Muhammadiyah 1 Surabaya yang beralamat di Jalan Kapasan No. 74-75 Surabaya. Waktu pelaksanaan penelitian ini tanggal 22 April 2016 sampai 27 April 2016 pada semester genap tahun ajaran 2015/2016.

Populasi dalam penelitian ini adalah seluruh siswa kelas X SMA Muhammadiyah 1 Surabaya sebanyak 5 kelas, yaitu kelas X-1, X-2, X-3, X-4, dan X-5. Karena seluruh siswa memiliki kemampuan yang homogen, maka sampel dari penelitian ini diambil secara random dengan persetujuan guru matematika, sehingga terpilih sampel penelitian yaitu kelas X-2 yang terdiri dari 35 siswa, kelas X-3 yang terdiri dari 31 siswa dan X-5 yang terdiri dari 31 siswa. Dalam penelitian ini kelas X-2 dijadikan sebagai kelas uji coba, kelas X-3 dijadikan sebagai kelas kontrol dan kelas X-5 sebagai kelas eksperimen.

Penelitian dilakukan dengan tiga tahap yaitu: tahap persiapan, tahap pelaksanaan, tahap pengelolaan dan analisis data. Secara garis besar kegiatankegiatan yang dilakukan adalah sebagai berikut:

1. Tahap Persiapan

a. Melakukan observasi ke sekolah yang dijadikan tempat penelitian.

b. Menyusun dan menetapkan pokok bahasan yang akan digunakan untuk penelitian. 
c. Menyusun rencana pelaksanaan pembelajaran (RPP) yang sudah di konsultasikan ke dosen pembimbing.

d. Menyusun perangkat pembelajaran yang kemudian dikonsultasikan pada kedua dosen pembimbing sampai mendapatkan persetujuan.

e. Melakukan uji coba instrumen untuk mengetahui validitas dan reliabilitas dari instrumen.

f. Analisis uji coba instrumen.

g. Menentukan sampel penelitian. Dilakukan dengan pemilihan kelas eksperimen dan kelas kontrol secara random.

2. Tahap Pelaksanaan

a. Memberikan pretest pada kelas eksperimen dan kelas kontrol untuk mengetahui hasil belajar siswa

b. Melakukan proses pembelajaran dengan menerapkan metode mnemonik pada kelas eksperimen.

c. Melakukan proses pembelajaran dengan menggunakan metode ceramah pada kelas kontrol.

d. Melakukan pengamatan aktivitas siswa selama proses pembelajaran.

e. Memberikan posttest pada kelas eksperimen dan kelas kontrol untuk mengetahui hasil belajar akhir siswa.

f. Memberikan angket respon siswa pada kelas eksperimen.

g. Mengolah data hasil penelitian.

3. Tahap Pengelolaan dan Analisis Data

a. Menskor pretest dan posttest data untuk mengetahui hasil belajar siswa.

b. Mengolah data kelas kontrol dan kelas eksperimen.

c. Menghitung data aktivitas siswa.

d. Menghitung angket respon siswa.

e. Membuat penafsiran dari kesimpulan hasil penelitian.

Data-data yang diperlukan dalam penelitian ini dilakukan dengan langkahlangkah sebagai berikut:

1. Sebelum Penelitian

a. Membuat proposal penelitian yang dikonsultasikan dengan dosen pembimbing sampai mendapatkan persetujuan. 
b. Melakukan uji validitas dan realibilitas terhadap soal yang akan diujikan.

c. Observasi lapangan untuk mengidentifikasi masalah dan memperoleh data-data awal di lapangan.

d. Memberikan pretest untuk mengetahui kemampuan awal siswa baik pada kelas eksperimen maupun pada kelas kontrol.

2. Proses Penelitian

a. Mendapatkan informasi mengenai aktifitas siswa terhadap pembelajaran dari Lembar Kerja Siswa (LKS) yang digunakan dalam pembelajaran.

b. Memperoleh data angket respon siswa pada kelas eksperimen.

c. Memperoleh posttest hasil belajar siswa baik pada kelas eksperimen dan pada kelas kontrol.

Untuk mendapatkan data dan informasi yang lengkap mengenai hal-hal yang ingin dikaji melalui penelitian ini, maka dibuatlah seperangkat instrumen. Adapun instrumen yang akan digunakan pada penelitian ini adalah sebagai berikut:

1. Seperangkat tes

Seperangkat tes ini terdiri dari 2 soal esai yang akan dikerjakan oleh siswa secara individu. Soal tes ini akan digunakan dalam soal pretest dan posttest.

2. Lembar Pengamatan Siswa

Indikator yang digunakan dalam menilai aktivitas siswa antara lain:

a. Mendengarkan atau memperhatikan penjelasan guru.

b. Siswa diberikan kesempatan untuk mengajukan pertanyaan dari penjelasan guru

c. Memahami LKS.

d. Berdiskusi kelompok dalam mengerjakan LKS

e. Mendengarkan kelompok lain saat presentasi

f. Mengajukan pertanyaan pada kelompok yang presentasi

g. Perilaku tidak relevan.

3. RPP

Rencana pelaksanaan pembelajaran (RPP) terlebih dahulu disusun oleh peneliti dan dikonsultasikan pada kedua dosen pembimbing dan guru yang mengajar pada kelas yang akan diteliti. 
Sebelum digunakan dalam penelitian, instrumen dikonsultasikan kepada dosen pembimbing dan guru matematika disekolah. Kemudian melakukan uji coba instrumen yang diujikan kepada siswa diluar sampel dengan karakteristik serupa pada sampel yang akan diteliti. Uji coba instrumen dilakukan untuk mengetahui validitas dan reliabilitas dari instrumen yang nantinya dapat digunakan untuk mengukur apa yang harus diukur. Validitas dan reliabilitas dihitung dengan menggunakan software SPSS versi 17.0.

Untuk mengetahui tingkat koefisien validitas secara empiris data akan dihitung dengan menggunakan korelasi product moment dengan angka angkar. Validitas dan reliabilitas dapat dihitung secara manual menggunakan rumus korelasi product moment.

Rumus korelasi product moment dengan angka kasar menurut Arikunto (2013:87), yaitu:

$$
r_{x y}=\frac{N \sum X Y-\left(\sum X\right)\left(\sum Y\right)}{\sqrt{\left\{N \sum X^{2}-\left(\sum X\right)^{2}\right\}\left\{N \sum Y^{2}-\left(\sum Y\right)^{2}\right\}}}
$$

Keterangan:

$r_{x y}=$ koefisien korelasi antara variabel $\mathrm{X}$ dan variabel $\mathrm{Y}$, dua variabel yang dikorelasikan.

$\mathrm{N}$ = banyaknya peserta test.

$\mathrm{X}=$ nilai hasil uji coba

$\mathrm{Y}=$ total nilai untuk $\mathrm{n}$ siswa

Besarnya interpretasi koefisien korelasi disajikan pada tabel 3.1 menurut Arikunto (2013:89) adalah sebagai berikut:

Tabel 3.1 Tabel Kriteria Validitas

\begin{tabular}{|c|c|}
\hline Nilai & Interpretasi Validitas \\
\hline $0,800<r_{x y} \leq 1,00$ & Sangat Tinggi \\
\hline $0,600<r_{x y} \leq 0,800$ & Tinggi \\
\hline $0,400<r_{x y} \leq 0,600$ & Cukup \\
\hline $0,200<r_{x y} \leq 0,400$ & Rendah \\
\hline$r_{x y} \leq 0,200$ & Sangat Rendah \\
\hline
\end{tabular}


Reliabilitas instrumen soal tes siswa dihitung dengan dengan menggunakan software SPSS versi 17.0. Secara manual dapat diukur menggunakan rumus Cronbach's Alpha, yaitu: (Arikunto, 2013:122)

Rumus Cronbach's Alpha: $\quad r_{11}=\left[\frac{k}{(k-1)}\right]\left[1-\frac{\sum S_{i^{2}}}{S_{t}^{2}}\right]$

Rumus varians butir soal : $S_{i}{ }^{2}=\frac{\sum X_{i}{ }^{2}-\frac{\left(\sum X_{i}\right)^{2}}{n}}{n}$

Rumus varians total: $S_{t}{ }^{2}=\frac{\sum X^{2}-\frac{\left(\sum X\right)^{2}}{n}}{n}$

Dengan: $\quad r_{11}=$ koefisien reliabilitas instrumen

$\mathrm{k} \quad=$ jumlah butir soal

$\sum S_{i^{2}} \quad=$ jumlah varians dari skor soal

$S_{t}{ }^{2} \quad=$ varians total

$\mathrm{n} \quad=$ jumlah siswa

$\mathrm{X} \quad=$ nilai skor yang dipilih

Ket:

$r \quad=$ reliabilitas instrumen.

$k=$ banyaknya butir pertanyaan atau banyaknya soal.

$\sum \sigma_{b}^{2}=$ jumlah varians butir atau skor tiap-tiap item.

$\sigma_{t}^{2}=$ total varians.

Tolak ukur untuk menginterpretasikan reliabilitas tes disajikan pada tabel 3.2 berikut:

Tabel 3.2 Kriteria Reliabilitas

\begin{tabular}{|c|c|}
\hline Nilai & Interpretasi \\
\hline $0,90<r_{11} \leq 1,00$ & Reliabilitas Sangat Tinggi \\
\hline $0,70<r_{11} \leq 0,90$ & Reliabilitas Tinggi \\
\hline $0,40<r_{11} \leq 0,70$ & Reliabilitas Sedang \\
\hline $0,20<r_{11} \leq 0,40$ & Reliabilitas Rendah \\
\hline$r \leq 0,20$ & Reliabilitas Sangat Rendah \\
\hline
\end{tabular}

Analisis yang dilakukan yaitu analisis pada data hasil test dan data aktivitas siswa. Analisis data hasil test tersebut meliputi data pretest dan data posttest. Berikut ini langkah-langkah yang dilakukan untuk mengolah data hasil pretest/posttest dengan: 
1. Uji Normalitas

Menguji normalitas data hasil pretest pada kelas eksperimen dan kelas kontrol dengan tujuan mengetahui apakah data skor pretest sampel berasal dari populasi yang berdistribusi normal. Uji normalitas dihitung dengan menggunakan software SPSS versi 17.0.

Perumusan hipotesis yang akan diuji adalah sebagai berikut:

$H_{0}$ : Data tes awal berasal dari populasi yang berdistribusi normal

$H_{1}$ : Data tes awal berasal dari populasi yang berdistribusi tidak normal

Dalam pengujian hipotesis, kriteria untuk menolak dan tidak menolak berdasarkan $P$-value adalah sebagai berikut:

a. Jika dengan $P$-value $>\alpha$, maka $H_{0}$ diterima

b. Jika dengan $P$-value $<\alpha$, maka $H_{0}$ ditolak

Selanjutnya dalam pengujian hipotesis, kriteria untuk menolak dan tidak menolak berdasarkan Kolmogorov-Smirnov adalah sebagai berikut:

a. Jika dengan $K s_{\text {tabel }} \geq K s_{\text {hitung }}$, maka $H_{0}$ diterima

b. Jika dengan $K s_{\text {tabel }}<K s_{\text {hitung }}$, maka $H_{0}$ ditolak

Untuk menguji kenormalan distribusi pada kelas eksperimen dan kelas kontrol dapat digunakan uji kolmogorov-smirnov. Rumus yang digunakan untuk melakukan uji kolmogorov-smirnov yaitu:

$$
k=\left|f\left(Z_{i}\right)-S\left(Z_{i}\right)\right|
$$

Keterangan:

$f\left(Z_{i}\right) \quad=$ Probabilitas komulatif normal

$S\left(Z_{i}\right) \quad=$ Probabilitas komulatif empiris

Signifikansi:

Signifikansi uji kolmogorov-smirnov yaitu dengan membandingkan nilai terbesar $\left|f\left(Z_{i}\right)-S\left(Z_{i}\right)\right|$ dengan nilai tabel kolmogorov-smirnov. Jika nilai $\left|f\left(Z_{i}\right)-S\left(Z_{i}\right)\right|$ terbesar kurang dari nilai tabel kolmogorov-smirnov, maka $H_{0}$ diterima: $H_{1}$ ditolak sehingga data dinyatakan berdistribusi normal. Jika nilai $\left|f\left(Z_{i}\right)-S\left(Z_{i}\right)\right|$ terbesar lebih dari nilai tabel kolmogorov-smirnov, maka $H_{0}$ ditolak: $H_{1}$ diterima sehingga data tidak berdistribusi normal. 


\section{Uji Homogenitas}

Melakukan uji homogenitas data hasil pretest dengan tujuan untuk mengetahui kesamaan dua varians antara kelas eksperimen dan kelas kontrol. Uji homogenitas dihitung dengan menggunakan software SPSS versi 17.0.

Untuk menguji kesamaan varians yang berdistribusi normal digunakan homogenitas. Pasangan hipotesis yang akan diuji adalah:

$H_{0}$ : Tidak ada perbedaan varians atau hasil belajar siswa antara kelas eksperimen dan kelas kontrol, berarti kedua kelas homogen.

$H_{1}$ : Ada perbedaan varians atau hasil belajar siswa antara kelas eksperimen dan kelas control, berarti kedua kelas tidak homogen.

Kriteria untuk menerima dan menolak berdasarkan $P_{\text {value }}$ dalam pengujian hipotesis adalah sebagai berikut:

a. Jika dengan $P$-value $>\alpha$, maka $H_{0}$ diterima

b. Jika dengan $P$-value $<\alpha$, maka $H_{0}$ ditolak

Kriteria pengujian: Terima $H_{0}$ untuk $F_{\text {hitung }} \leq F_{\text {tabel }}$

$$
F_{\text {hitung }}=\frac{S_{1}{ }^{2}}{S_{2}{ }^{2}} \quad \text { (Sudjana, 2005: 95) }
$$

Rumus varians yaitu:

$$
s^{2}=\frac{n \sum f_{i} x_{i}{ }^{2}-\left(\sum f_{i} x_{i}\right)^{2}}{n(n-1)}
$$

Keterangan:

$S_{1}^{2}=$ varians terbesar.

$S_{2}{ }^{2}=$ varians terkecil.

3. Melakukan uji perbedaan dua rata-rata (Uji $t)$.

Setelah sampel diberi perlakuan yang berbeda, maka dilaksanakan tes akhir. Dari hasil tes akhir ini akan diperoleh data yang digunakan sebagai dasar dalam penilaian, yaitu hipotesis diterima atau ditolak. Uji perbedaan dua rata-rata (Uji $t$ ).dihitung dengan menggunakan software SPSS versi 17.0.

Adapun hipotesis yang dirumuskan adalah sebagai berikut: 
Uji hipotesis yang digunakan adalah uji perbedaan rata-rata hasil tes yaitu uji satu pihak (uji pihak kanan) dengan rumus hipotesisnya adalah sebagai berikut:

$H_{0}: \mu_{1}=\mu_{2}$ atau $H_{0}: \mu_{1}-\mu_{2}=0$, artinya tidak terdapat perbedaan ratarata skor tes akhir antara kelas eksperimen dan kelas kontrol.

$H_{1}: \mu_{1} \neq \mu_{2}$ atau $H_{1}: \mu_{1}-\mu_{2} \neq 0$, artinya terdapat perbedaan rata-rata skor tes akhir antara kelas eksperimen dan kelas kontrol.

Keterangan:

$\mu_{1}=$ rata-rata hasil belajar

Dalam pengujian hipotesis, kriteria untuk menolak dan tidak menolak berdasarkan $P$-value adalah sebagai berikut:

a. Jika dengan $P$-value $>\alpha$, maka $H_{0}$ diterima

b. Jika dengan $P$-value $<\alpha$, maka $H_{0}$ ditolak

Selanjutnya dalam pengujian hipotesis, kriteria untuk daerah penolakan dan penerimaan berdasarkan Uji One Samples Test posttest adalah sebagai berikut:

a. Jika $t_{\text {tabel }} \geq t_{\text {hitung }}$, maka $H_{0}$ diterima

b. Jika $t_{\text {tabel }} \leq t_{\text {hitung }}$, maka $H_{0}$ ditolak

Kriteria pengujian: Terima $H_{0}$ untuk $-t_{\text {tabel }}<t_{\text {hitung }}<t_{\text {tabel }}$

$$
\begin{aligned}
& t_{\text {hitung }}=\frac{\bar{X}_{1}-\bar{X}_{2}}{S} \\
& \mathrm{~S}_{\text {gab }}=\sqrt{\frac{\left(\mathrm{n}_{1}-1\right) \mathrm{s}_{1}^{2}+\left(\mathrm{n}_{2}-1\right) \mathrm{s}_{2}^{2}}{\mathrm{n}_{2}}}
\end{aligned}
$$

Keterangan :

$\bar{X}_{1}$ : skor rata-rata dari kelas eksperimen

$\bar{X}_{2}$ : skor rata-rata dari kelas kontrol

$n_{1}$ : banyaknya subyek kelas eksperimen

$n_{2}$ : banyaknya subyek kelas kontrol

$s_{1}^{2}$ : varians kelas eksperimen 
$s_{2}^{2}$ : varians kelas kontrol

$S_{g a b}:$ varians gabungan

Analisis Keaktifan Siswa dengan Teknik Presentase (\%) setiap indikator digunakan rumus:

$$
K_{s}=\frac{\text { Skor Total }}{\text { Skor Maksimal }} \times 100 \%
$$

Keterangan

$K s$

$=$ Keaktifan Siswa

Skor total $=$ Skor total dari jumlah aktifitas siswa yang muncul selama proses pembelajaran

Skor maksimal $=$ Skor maksimal yang diperoleh jika siswa melakukan semua aktifitas yang diharapkan muncul.

Analisis data hasil angket respon siswa setelah pembelajaran dianalisis menggunakan persentase dari respons siswa. Persentase ini menggunakan rumus:

$$
P=\frac{f}{N} \times 100 \%
$$

Keterangan:

$P \quad=$ Persentase respon siswa

$f \quad=$ Frekuensi jawaban untuk kategori tertentu

$N=$ Banyak siswa atau responden yang mengisi angket

Respon siswa dikatakan positif jika persentase siswa dalam menjawab "sangat setuju" dan "setuju" lebih banyak dari pada persentase siswa menjawab "tidak setuju" dan "sangat tidak setuju".

\section{HASIL PENELITIAN DAN PEMBAHASAN}

Apabila terbukti ada perbedaan rata-rata skor tes akhir siswa antara kelompok eksperimen dan kelompok kontrol maka dilakukan uji t. Uji t yang digunakan adalah Independent Samples t-Test yang terdapat pada software SPSS ver 17.0 for windows dengan asumsi kedua varians homogen (equel varians assumed). 
Hipotesis yang akan diuji adalah sebagai berikut:

$H_{0}: \mu_{1}=\mu_{2}$ atau $H_{0}: \mu_{1}-\mu_{2}=0$, artinya tidak terdapat perbedaan rata-rata skor tes awal antara kelas eksperimen dan kelas kontrol.

$H_{1}: \mu_{1} \neq \mu_{2}$ atau $H_{1}: \mu_{1}-\mu_{2} \neq 0$, artinya terdapat perbedaan rata-rata skor tes awal antara kelas eksperimen dan kelas kontrol.

Dalam pengujian hipotesis, kriteria untuk menolak dan tidak menolak berdasarkan $P$-value adalah sebagai berikut:

1. Jika dengan $P$-value $>\alpha$, maka $H_{0}$ diterima

2. Jika dengan $P$-value $<\alpha$, maka $H_{0}$ ditolak

Pada program SPSS digunakan istilah significance (yang disingkat Sig.) untuk $P$-value, dengan kata lain $P$-value $=S i g$. Adapun taraf signifikansi yang digunakan adalah 2,5\% atau 0,025. Hasil pengujian diperlihatkan pada Tabel 1 .

Tabel 1. Uji Perbedaan Dua Rata-rata Posttest 2 Independent Samples Test

\begin{tabular}{|c|c|c|c|c|c|c|c|c|c|c|}
\hline & & \multicolumn{2}{|c|}{$\begin{array}{c}\text { Levene's Test } \\
\text { for Equality of } \\
\text { Variances }\end{array}$} & \multicolumn{7}{|c|}{ t-test for Equality of Means } \\
\hline & & \multirow[b]{2}{*}{$\mathrm{F}$} & \multirow[b]{2}{*}{ Sig. } & \multirow[b]{2}{*}{$\mathrm{T}$} & \multirow[b]{2}{*}{ df } & \multirow{2}{*}{$\begin{array}{l}\text { Sig. (2- } \\
\text { tailed) }\end{array}$} & \multirow{2}{*}{$\begin{array}{c}\text { Mean } \\
\text { Difference }\end{array}$} & \multirow{2}{*}{$\begin{array}{l}\text { Std. Error } \\
\text { Difference }\end{array}$} & \multicolumn{2}{|c|}{$\begin{array}{c}95 \% \\
\text { Confidence } \\
\text { Interval of the } \\
\text { Difference }\end{array}$} \\
\hline & & & & & & & & & Lower & Upper \\
\hline Posttest_2 & $\begin{array}{l}\text { Equal } \\
\text { variances } \\
\text { assumed } \\
\text { Equal } \\
\text { variances } \\
\text { not } \\
\text { assumed }\end{array}$ & 1.114 & .296 & $\begin{array}{l}3.078 \\
3.087\end{array}$ & 59 & .003 & 9.142 & 2.970 & 3.200 & 15.085 \\
\hline
\end{tabular}

Berdasarkan Tabel 1, terlihat bahwa nilai signifikan (Sig) yang mengacu pada uji $t$-Test for Equality of Means diperoleh nilai signifikan nilai posttest dari kedua kelas tersebut adalah 0,003. Nilai signifikan kedua kelas tersebut kurang dari 0,025 atau $P$-value $\leq \alpha$. maka $H_{0}$ ditolak.

Selanjutnya dalam pengujian hipotesis, kriteria untuk daerah penolakan dan penerimaan berdasarkan Uji Independent Samples Test pretest adalah sebagai berikut: 
1. Jika $t_{\text {tabel }} \geq t_{\text {hitung }}$, maka $H_{0}$ diterima

2. Jika $t_{\text {tabel }}<t_{\text {hitung }}$, maka $H_{0}$ ditolak

Berdasarkan Tabel 1, terlihat bahwa nilai $t_{\text {tabel }}$ pada uji $t$-Test for Equality of Means dengan taraf signifikan kedua kelas tersebut 0,025 adalah 3,078. Dengan nilai kritis $t$ untuk taraf nyata 0,025 dan $d f=59$ adalah 2,00030. Karena $t_{\text {tabel }}=$ $2,00030<t_{\text {hitung }}=3,078$ maka $H_{0}$ ditolak.

Pada tabel 95\% confidence interval of difference menunjukkan nilai lower adalah 3,200 dan 3,215 sedangkan nilai upper adalah 15,085 dan 15,070. Hal ini menunjukkan bahwa terdapat perbedaan rata-rata skor tes awal antara kelas eksperimen dan kelas kontrol yang berkisar antara 3,200 sampai 15,085.

Berdasarkan hasil pengujian P-value danUji Independent Samples Test posttest 2 diatas, dapat disimpulkan bahwa terdapat perbedaan rata-rata skor posttest 2 antara kelas eksperimen dan kelas kontrol.

Pengolahan data hasil aktivitas siswa ini dilakukan dengan menggunakan bantuan software Microsoft Excel 2007. Pada Tabel 2 akan disajikan hasil analisis presentase aktivitas siswa kelas eksperimen pada pertemuan I, II,III dan pertemuan IV.

\section{Tabel 2. Hasil Presentase Aktivitas Siswa Kelas Ekperimen Pada Pertemuan} I, II, III dan Pertemuan IV

\begin{tabular}{|c|l|c|c|c|c|c|}
\hline Kode & \multicolumn{1}{|c|}{ Aktivitas Siswa } & P1 & P2 & P3 & P4 & $\begin{array}{c}\text { Rata- } \\
\text { rata }\end{array}$ \\
\hline 1 & $\begin{array}{l}\text { Mendengarkan atau memperhatikan penjelasan } \\
\text { guru. }\end{array}$ & 33 & 15 & 35 & 16 & 24,8 \\
\hline 2 & $\begin{array}{l}\text { Siswa diberikan kesempatan untuk mengajukan } \\
\text { pertanyaan dari penjelasan guru }\end{array}$ & 2 & 0 & 2 & 0 & 1,0 \\
\hline 3 & Memahami LKS. & 14 & 17 & 13 & 16 & 15,0 \\
\hline 4 & Berdiskusi kelompok dalam mengerjakan LKS & 48 & 0 & 48 & 0 & 24,0 \\
\hline 5 & Mendengarkan kelompok lain saat presentasi & 0 & 46 & 0 & 47 & 23,3 \\
\hline 6 & $\begin{array}{l}\text { Mengajukan pertanyaan pada kelompok yang } \\
\text { presentasi }\end{array}$ & 0 & 17 & 0 & 18 & 8,8 \\
\hline 7 & Perilaku tidak relevan. & 3 & 4,3 & 12 & 3 & 5,6 \\
\hline
\end{tabular}

Berdasarkan Tabel 2, terlihat bahwa aktivitas dominan yang pertama yang presentase terbesar dilakukan siswa adalah pada saat mendengarkan atau memperhatikan penjelasan guru. Hal ini terlihat pada kode (1), bahwa 
mendengarkan atau memperhatikan penjelasan guru memperoleh persentase sebesar $24,8 \%$.

Aktivitas dominan yang kedua yaitu berdiskusi kelompok dalam mengerjakan LKS. Hal ini terlihat pada kode (4), bahwa berdiskusi kelompok dalam mengerjakan LKS memperoleh persentase sebesar $24 \%$.

Aktivitas dominan yang ketiga yaitu mendengarkan kelompok lain saat presentasi. Hal ini terlihat pada kode (5), bahwa mendengarkan kelompok lain saat presentasi memperoleh persentase sebesar $23,3 \%$.

Selanjutnya kode (7) dan (2) bahwa memahami LKS dan Mengajukan pertanyaan pada kelompok yang presentasi memperoleh persentase masingmasing sebesar $15 \%$ dan $8,8 \%$.

Pada kode (3) dan (6) bahwa memahami perilaku tidak relevan dan siswa diberikan kesempatan untuk mengajukan pertanyaan dari penjelasan guru memperoleh persentase masing-masing sebesar 5,6\% dan $1 \%$.

Angket respons siswa terhadap penggunaan pembelajaran metode mnemonik terdiri dari 10 pernyataan dengan empat pilihan jawaban yakni SS (Sangat Setuju), S (Setuju), TS (Tidak Setuju), dan STS (Sangat Tidak Setuju). Pernyataan-pernyataan pada angket respons siswa bertujuan untuk mengetahui bagaimana ketertarikan siswa dalam pembelajaran metode mnemonik dalam pelajaran matematika dikelas. Angket respon siswa ini diberikan di akhir pembelajaran (setelah pembelajaran metode mnemonik). Hasil data jumlah dan presentase angket respons siswa pada pembelajaran metode mnemonik dapat dilihat pada tabel 3 .

\section{Tabel 3. Hasil Jumlah dan Presentase Respon Siswa Terhadap Pembelajaran Metode Mnemonik}

\begin{tabular}{|c|l|c|c|c|c|}
\hline \multirow{2}{*}{ No. } & \multicolumn{1}{|c|}{ Pernyataan } & \multicolumn{3}{|c|}{ Jumlah dan Presentase (\%) } \\
\cline { 3 - 6 } & \multicolumn{1}{|c|}{$\begin{array}{c}\text { Sangat } \\
\text { Setuju }\end{array}$} & Setuju & $\begin{array}{c}\text { Tidak } \\
\text { Setuju }\end{array}$ & $\begin{array}{c}\text { Sangat } \\
\text { Tidak } \\
\text { Setuju }\end{array}$ \\
\hline 1 & $\begin{array}{l}\text { Pembelajaran matematika dengan metode } \\
\text { mnemonik membuat saya senang terhadap } \\
\text { pelajaran matematika. }\end{array}$ & $\begin{array}{c}9 \\
(29 \%)\end{array}$ & $\begin{array}{c}19 \\
(61,3 \%)\end{array}$ & 3 & 0 \\
\hline 2 & $\begin{array}{l}\text { Pembelajaran matematika dengan metode } \\
\text { mnemonik berbeda dengan pembelajaran } \\
\text { matematika yang biasa dilakukan. }\end{array}$ & $\begin{array}{c}10 \\
(32,3 \%)\end{array}$ & $\begin{array}{c}20 \\
(64,5 \%)\end{array}$ & 0 & 1 \\
\hline 3 & Pembelajaran dengan metode mnemonik & 11 & 18 & 2 & 0 \\
\hline
\end{tabular}


Pengaruh model pembelajaran kooperatif tipe STAD dengan metode mnemonik terhadap hasil belajar Siswa kelas X di SMA Muhammadiyah 1 Surabaya

\begin{tabular}{|c|c|c|c|c|c|}
\hline \multirow[b]{2}{*}{ No. } & \multirow[b]{2}{*}{ Pernyataan } & \multicolumn{4}{|c|}{ Jumlah dan Presentase (\%) } \\
\hline & & $\begin{array}{l}\text { Sangat } \\
\text { Setuju }\end{array}$ & Setuju & $\begin{array}{l}\text { Tidak } \\
\text { Setuju }\end{array}$ & $\begin{array}{l}\text { Sangat } \\
\text { Tidak } \\
\text { Setuju }\end{array}$ \\
\hline & $\begin{array}{l}\text { memudahkan saya untuk memahami } \\
\text { materi. }\end{array}$ & $(35,5 \%)$ & $(58,1 \%)$ & $(6,5 \%)$ & - \\
\hline 4 & $\begin{array}{l}\text { Belajar matematika menggunakan metode } \\
\text { mnemonik membuat materi mudah } \\
\text { diingat. }\end{array}$ & $\begin{array}{c}12 \\
(38,7 \%)\end{array}$ & $\begin{array}{c}17 \\
(54,8 \%)\end{array}$ & $\begin{array}{c}2 \\
(6,5 \%)\end{array}$ & $\begin{array}{l}0 \\
-\end{array}$ \\
\hline 5 & $\begin{array}{l}\text { Saya lebih senang pembelajaran } \\
\text { matematika dengan metode mnemonik } \\
\text { dibandingkan pembelajaran biasa } \\
\text { (konvensional). }\end{array}$ & $\begin{array}{c}9 \\
(29 \%) \\
\end{array}$ & $\begin{array}{c}12 \\
(38,7 \%)\end{array}$ & $\begin{array}{c}8 \\
(25,8 \%)\end{array}$ & $\begin{array}{c}2 \\
(6,5 \%) \\
\end{array}$ \\
\hline 6 & $\begin{array}{l}\text { Saya senang dengan pembelajaran } \\
\text { matematika dengan metode mnemonik } \\
\text { karena saya dapat sharing baik bersama } \\
\text { teman maupun guru. }\end{array}$ & $\begin{array}{c}8 \\
(25,8 \%)\end{array}$ & $\begin{array}{c}23 \\
(74,2 \%)\end{array}$ & $\begin{array}{l}0 \\
-\end{array}$ & $\begin{array}{l}0 \\
-\end{array}$ \\
\hline 7 & $\begin{array}{l}\text { Pembelajaran matematika dengan metode } \\
\text { mnemonik bermanfaat bagi saya. }\end{array}$ & $\begin{array}{c}10 \\
(32,3 \%)\end{array}$ & $\begin{array}{c}19 \\
(61,3 \%)\end{array}$ & $\begin{array}{c}1 \\
(3,2 \%)\end{array}$ & $\begin{array}{c}1 \\
(3,2 \%)\end{array}$ \\
\hline 8 & $\begin{array}{l}\text { Belajar matematika menggunakan metode } \\
\text { mnemonik membuat saya merasa lebih } \\
\text { termotivasi. }\end{array}$ & $\begin{array}{c}5 \\
(16,1 \%)\end{array}$ & $\begin{array}{c}23 \\
(74,2 \%)\end{array}$ & $\begin{array}{c}3 \\
(9,7 \%)\end{array}$ & $\begin{array}{l}0 \\
-\end{array}$ \\
\hline 9 & $\begin{array}{l}\text { Belajar matematika menggunakan metode } \\
\text { mnemonik membuat saya lebih aktif dalam } \\
\text { belajar. }\end{array}$ & $\begin{array}{c}7 \\
(22,6 \%)\end{array}$ & $\begin{array}{c}19 \\
(61,3 \%)\end{array}$ & $\begin{array}{c}3 \\
(9,7 \%)\end{array}$ & $\begin{array}{c}2 \\
(6,5 \%)\end{array}$ \\
\hline 10 & $\begin{array}{l}\text { Metode mnemonik membuat pelajaran } \\
\text { matematika lebih menarik untuk dipelajari. }\end{array}$ & $\begin{array}{c}10 \\
(32,3 \%)\end{array}$ & $\begin{array}{c}20 \\
(64,5 \%)\end{array}$ & $\begin{array}{l}0 \\
-\end{array}$ & $\begin{array}{c}1 \\
(3,2 \%) \\
\end{array}$ \\
\hline & Rata-rata Presentase $(\%)$ & $(29,4 \%)$ & $(61,3 \%)$ & $(71, \%)$ & $(2,3 \%)$ \\
\hline
\end{tabular}

Pernyataan dalam angket respon siswa ini terbagi menjadi 2 kategori yaitu respon positif (SS dan S) dan respons negatif (TS dan STS). Kategori respon positif didapatkan jika presentase siswa menjawab Sangat Setuju (SS) dan Setuju (S) lebih besar daripada presentase siswa menjawab Tidak Setuju (TS) dan Sangat Tidak Setuju (STS). Sebaliknya kategori respon negatif didapatkan jika presentase siswa menjawab Sangat Setuju (SS) dan Setuju (S) lebih sedikit daripada presentase siswa menjawab Tidak Setuju (TS) dan Sangat Tidak Setuju (STS).

Pada hasil presentase angket respon siswa pada Tabel 3, terlihat bahwa (pada pernyataan angket positif) $29,4 \%$ siswa Sangat Setuju dan $61,3 \%$ Setuju dengan pembelajaran metode mnemonik pada pelajaran matematika dengan materi Trigonometri, ini berarti bahwa banyak siswa pada kelompok kelas eksperimen merespon baik terhadap pembelajaran metode mnemonik dikelas.

Data yang diperoleh dari penelitian ini adalah data kuantitatif hasil pretest/ posttest 1 dan posttest 2 pada kelas eksperimen dan kelas kontrol. Pretest /posttest 


\section{Marissa Yuliana ${ }^{1}$, Wahyuni Suryaningtyas ${ }^{2}$, Shoffan Shoffa ${ }^{3}$}

1 dilaksanakan dengan menggunakan soal berbentuk uraian sebanyak 2 butir soal dan posttest 2 dilaksanakan dengan menggunakan soal berbentuk uraian sebanyak 2 butir soal dengan harapan nilai maksimal yang didapat ialah 100. Pengolahan data kuantitatif dilakukan dengan menggunakan bantuan software SPSS versi 17.0 for windows. Pada data hasil penelitian dilakukan analisis meliputi pengujian normalitas, pengujian homogenitas, dan pengujian perbedaan dua rata-rata.

Berdasarkan hasil pretest dengan uji normalitas diketahui bahwa nilai $K s_{\text {hitung }}$ dengan taraf signifikan kedua kelas tersebut 0,05 adalah 0,148 pada kelas ekperimen dan 0,177 pada kelas kontrol. Nilai kritis $K s$ dengan taraf nyata 0,05 adalah 0,244 pada kelas eksperimen dan 0,244 pada kelas kontrol. Karena pada kelas Eksperimen $K s_{\text {tabel }}=0,244 \geq K s_{\text {hitung }}=0,148$ dan pada kelas Kontrol $K s_{\text {tabel }}=0,244 \geq K s_{\text {hitung }}=0,177$, maka hasil pretest pada kelas eksperimen dan kelas kontrol dinyatakan berdistribusi normal. Pada uji homogenitas taraf signifikansi yang digunakan adalah $5 \%(\alpha=0,05)$ dan dari hasil pengujian homogeneity varians dengan Levene Statistik menunjukkan nilai 1,352 dengan $P$-value $=$ signifikansi (Sig.) adalah 0,279. Oleh karena nilai signifikansi $P$-value $>\alpha$ maka dapat disimpulkan bahwa tidak terdapat perbedaan hasil belajar matematika antara kelas eksperimen dan kelas control (homogen). Berdasarkan uji perbedaan dua rata-rata (uji t) terlihat bahwa nilai taraf signifikan ( $\mathrm{Sig}$ ) yang yang digunakan adalah 2,5\% atau 0,025. Nilai $t_{\text {tabel }}$ pada uji $t$-Test for Equality of Means dengan taraf signifikan kedua kelas tersebut 0,025 adalah $-1,369$. Dengan nilai kritis $t$ untuk taraf nyata 0,025 dan $d f=60$ adalah 2,00030. Karena $t_{\text {tabel }}=2,00030 \geq t_{\text {hitung }}=-1,369$, maka $H_{0}$ diterima. Pada $95 \%$ confidence interval of difference menunjukkan nilai lower adalah $-4,922$ dan $-4,923$ sedangkan nilai upper adalah 0,922 dan 0,923. Hal ini menunjukkan bahwa tidak terdapat perbedaan rata-rata skor tes awal antara kelas eksperimen dan kelas kontrol.

Berdasarkan hasil posttest 1 diketahui bahwa nilai $K s_{\text {hitung }}$ dengan taraf signifikan kedua kelas tersebut 0,05 adalah 0,122 pada kelas ekperimen dan 0,160 pada kelas kontrol. Nilai kritis $K s$ dengan taraf nyata 0,05 adalah 0,244 pada kelas eksperimen dan 0,244 pada kelas kontrol. Karena $K s_{\text {tabel }}=0,244 \geq$ 
Pengaruh model pembelajaran kooperatif tipe STAD dengan metode mnemonik terhadap hasil belajar Siswa kelas X di SMA Muhammadiyah 1 Surabaya

$K s_{\text {hitung }}=0,122$ dan $K s_{\text {tabel }}=0,244 \geq K s_{\text {hitung }}=0,160$, maka dapat diambil kesimpulan bahwa sampel kelas eksperimen dan kelas kontrol dinyatakan berdistribusi normal. Pada uji homogenitas taraf signifikansi yang digunakan adalah $5 \%(\alpha=0,05)$ dan dari hasil pengujian homogeneity varians dengan Levene Statistik menunjukkan nilai 2,780 dengan $P$-value $=$ signifikansi (Sig.) adalah 0,035. Oleh karena nilai signifikansi $P$-value $<\alpha$ maka $H_{0}$ ditolak. Berdasarkan hasil pengujian dapat disimpulkan bahwa terdapat perbedaan hasil belajar matematika antara kedua sampel (homogen). Berdasarkan uji perbedaan dua rata-rata (uji t) terlihat bahwa nilai taraf signifikan (Sig) yang yang digunakan adalah 2,5\% atau 0,025. Nilai $t_{\text {tabel }} t_{\text {tabel }}$ pada uji $t$-Test for Equality of Means dengan taraf signifikan kedua kelas tersebut 0,025 adalah 3,354. Dengan nilai kritis $t$ untuk taraf nyata 0,025 dan $d f=60$ adalah 2,00030. Karena $t_{\text {tabel }}=$ $2,00030<t_{\text {hitung }}=3,354$, maka $H_{0}$ ditolak. Pada tabel 95\% confidence interval of difference menunjukkan nilai lower adalah 3,228 dan 3,221 sedangkan nilai upper adalah 12,772 dan 12,779. Hal ini menunjukkan bahwa terdapat perbedaan rata-rata skor tes awal antara kelas eksperimen dan kelas kontrol yang berkisar antara 3,228 sampai 12,772. Dapat disimpulkan bahwa terdapat perbedaan ratarata skor Posttest 1 antara kelas eksperimen dan kelas kontrol.

Berdasarkan hasil posttest 2 diketahui bahwa nilai $K s_{\text {hitung }}$ dengan taraf signifikan kedua kelas tersebut 0,05 adalah 0,132 pada kelas ekperimen dan 0,125 pada kelas kontrol. Nilai kritis $K s$ dengan taraf nyata 0,05 adalah 0,244 pada kelas eksperimen dan 0,244 pada kelas kontrol. Karena $K s_{\text {tabel }}=0,244 \geq$ $K s_{\text {hitung }}=0,132$ dan $K s_{\text {tabel }}=0,244 \geq K s_{\text {hitung }}=0,125, \quad$ maka dapat diambil kesimpulan bahwa sampel posttest 2 kelas eksperimen dan kelas kontrol dinyatakan berdistribusi normal. Pada uji homogenitas taraf signifikansi yang digunakan adalah $5 \%(\alpha=0,05)$ dan dari hasil pengujian homogeneity varians dengan Levene Statistik menunjukkan nilai 4,211 dengan $P$-value $=$ signifikansi (Sig.) adalah 0,005. Oleh karena nilai signifikansi $P$-value $<\alpha$ maka $H_{0}$ ditolak. Berdasarkan hasil pengujian Test of Homogenity of Variance diatas, dapat disimpulkan bahwa terdapat perbedaan hasil belajar matematika antara kedua sampel (homogen). Berdasarkan uji perbedaan dua rata-rata (uji t) terlihat bahwa 
nilai taraf signifikan (Sig) yang yang digunakan adalah 2,5\% atau 0,025. Nilai $t_{\text {tabel }}$ uji $t$-Test for Equality of Means dengan taraf signifikan kedua kelas tersebut 0,025 adalah 3,078. Dengan nilai kritis $t$ untuk taraf nyata 0,025 dan $d f=59$ adalah 2,00030. Karena $t_{\text {tabel }}=2,00030<t_{\text {hitung }}=3,078$ maka $H_{0}$ ditolak. Pada tabel $95 \%$ confidence interval of difference menunjukkan nilai lower adalah 3,200 dan 3,215 sedangkan nilai upper adalah 15,085 dan 15,070. Hal ini menunjukkan bahwa terdapat perbedaan rata-rata skor tes awal antara kelas eksperimen dan kelas kontrol yang berkisar antara 3,200 sampai 15,085. Dapat disimpulkan bahwa terdapat perbedaan rata-rata skor posttest 2 antara kelas eksperimen dan kelas kontrol.

Pengamatan aktivitas siswa hanya dilakukan di kelas eksperimen saja pada pertemuan I, II,III dan pertemuan IV. Berdasarkan Tabel 2, terlihat bahwa aktivitas dominan yang pertama yang presentase terbesar dilakukan siswa adalah pada saat mendengarkan atau memperhatikan penjelasan guru. Hal ini terlihat pada kode (1), bahwa mendengarkan atau memperhatikan penjelasan guru memperoleh persentase sebesar $24,8 \%$.

Aktivitas dominan yang kedua yaitu berdiskusi kelompok dalam mengerjakan LKS. Hal ini terlihat pada kode (4), bahwa berdiskusi kelompok dalam mengerjakan LKS memperoleh persentase sebesar $24 \%$.

Aktivitas dominan yang ketiga yaitu mendengarkan kelompok lain saat presentasi. Hal ini terlihat pada kode (5), bahwa mendengarkan kelompok lain saat presentasi memperoleh persentase sebesar 23,3\%.

Selanjutnya kode (7) dan (2) bahwa memahami LKS dan Mengajukan pertanyaan pada kelompok yang presentasi memperoleh persentase masingmasing sebesar $15 \%$ dan $8,8 \%$.

Pada kode (3) dan (6) bahwa memahami perilaku tidak relevan dan siswa diberikan kesempatan untuk mengajukan pertanyaan dari penjelasan guru memperoleh persentase masing-masing sebesar 5,6\% dan $1 \%$.

Angket respons siswa terhadap penggunaan pembelajaran metode mnemonik terdiri dari 10 pernyataan dengan empat pilihan jawaban yakni SS (Sangat Setuju), S (Setuju), TS (Tidak Setuju), dan STS (Sangat Tidak Setuju). Pernyataan-pernyataan pada angket respons siswa bertujuan untuk mengetahui 
bagaimana ketertarikan siswa dalam pembelajaran metode mnemonik dalam pelajaran matematika dikelas. Angket respon siswa ini diberikan di akhir pembelajaran (setelah pembelajaran metode mnemonik). Hasil data jumlah dan presentase angket respons siswa pada pembelajaran metode mnemonik dapat dilihat pada tabel 4.25 .

Pernyataan dalam angket respon siswa terbagi menjadi 2 kategori yaitu respon positif (SS dan S) dan respons negatif (TS dan STS). Kategori respon positif didapatkan jika presentase siswa menjawab Sangat Setuju (SS) dan Setuju (S) lebih besar daripada presentase siswa menjawab Tidak Setuju (TS) dan Sangat Tidak Setuju (STS). Sebaliknya kategori respon negatif didapatkan jika presentase siswa menjawab Sangat Setuju (SS) dan Setuju (S) lebih sedikit daripada presentase siswa menjawab Tidak Setuju (TS) dan Sangat Tidak Setuju (STS).

Pada hasil presentase angket respon siswa pada Tabel 3, terlihat bahwa (pada pernyataan angket positif) $29,4 \%$ siswa Sangat Setuju dan 61,3\% Setuju dengan pembelajaran metode mnemonik pada pelajaran matematika dengan materi Trigonometri, ini berarti bahwa banyak siswa pada kelompok kelas eksperimen merespon baik terhadap pembelajaran metode mnemonik dikelas.

\section{SIMPULAN}

Berdasarkan analisis hasil penelitian yang telah dilakukan oleh peneliti mengenai pengaruh metode mnemonik terhadap hasil belajar siswa kelas X SMA Muhammadiyah 1 Surabaya, dapat disimpulkan sebagai berikut:

1. Metode mnemonik berpegaruh positif dan signifikan terhadap hasil belajar siswa. Hal ini dilihat dari uji $t$, diperoleh posttest 1 dengan $t_{\text {tabel }}=2,00 \leq$ $t_{\text {hitung }}=3,35$ dan posttest 2 dengan $t_{\text {tabel }}=2,00 \leq t_{\text {hitung }}=3,07$, maka $H_{1}$ diterima sehingga didapatkan hasil bahwa rata-rata skor tes akhir pada kelompok eksperimen lebih baik daripada rata-rata skor tes akhir pada kelompok kontrol. Dari hasil penelitian ini dapat disimpulkan bahwa metode mnemonik berpegaruh positif dan signifikan terhadap hasil belajar siswa.

2. Pada hasil presentase angket respon siswa terlihat bahwa (pada pernyataan angket positif) $29,4 \%$ siswa Sangat Setuju dan 61,3\% Setuju dengan pembelajaran metode mnemonik pada pelajaran matematika dengan materi 
Trigonometri, ini berarti bahwa banyak siswa pada kelompok kelas eksperimen merespon baik terhadap pembelajaran metode mnemonik di kelas.

\section{DAFTAR PUSTAKA}

Alya, Qonita. 2009. Kamus Bahasa Indonesia Untuk Pendidikan Dasar. Anggota IKAPI: PT Indah Jaya Adipratama

Arifin, Zainal. 2012. Penelitian Pendidikan. Bandung: Remaja Rosdakarya.

Arikunto, Suharsimi. 2013. Dasar-Dasar Evaluasi Pendidikan. Jakarta: Bumi Aksara.

Asma, Nur. (2006). Model Pembelajaran Kooperatif. Jakarta: Depdiknas.

Asmarani, Kartika. 2013. Efektifitas Metode Mnemonik Dalam Meningkatkan Daya Ingat Siswa Kelas IX SMP Negeri 2 Satu Atap Sluke Pada Mata Pelajaran Sejarah. Semarang: Universitas Negeri Semarang.

Degeng, S.Nyoman.2013. Ilmu Pembelajaran. Bandung: Kalam Hidup.

Dewanti, Reivani Ayuning. 2014. Penerapan Metode Mnemonik dengan Media Kartu Berpasangan Untuk Meningkatkan Motivasi dan Hasil Belajar Siswa Pada Pelajaran Biologi Kelas VII SMP Negeri 1 Arjasa Jember. Jember: Universitas Jember.

Faizi, Mastur. 2013. Ragam Metode Mengajarkan Eksakta Pada Murid. Jogjakarta: Diva Press.

Fathurohman, Pupuh dan M. Sobry Sutikno. 2011. Strategi Belajar Mengajar. Bandung: Refika Aditama.

Gordon, Barry dan Lisa Berger. 2006. Memori Inteligen. Erlangga.

Hamalik, Oemar. 2004. Proses Belajar Mengajar. Jakarta: Bumi Aksara.

Hamzah, Ali dan Muhlisrarini. 2014. Perencanaan dan Strategi Pembelajaran Matematika. Jakarta: Rajagrafindo Persada.

Komara, Endang. 2014. Belajar dan Pembelajaran Interaktif. Bandung: Refika Aditama.

Mahfudz, Rosa Safurah. 2010. Pengaruh Pendekatan Saintifik Terhadap Hasil Belajar Siswa Kelas VII SMP Muhammadiyah 14 Surabaya. Surabaya: Universitas Muhammadiyah Surabaya. Skripsi tidak dipublikasikan. 
Pengaruh model pembelajaran kooperatif tipe STAD dengan metode mnemonik terhadap hasil belajar Siswa kelas X di SMA Muhammadiyah 1 Surabaya

Prastowo, Andi. 2013. Pengembangan Bahan Ajar Tematik. Jogjakarta: Diva Press.

Sanjaya, Wina. 2011. Strategi Pembelajaran Berorientasi Standar Proses Pendidikan. Jakarta: Kencana.

Sardiman. 2011. Interaksi dan Motivasi Belajar-Mengajar. Jakarta: Rajawali Pers

Slameto. 2010. Belajar dan Faktor- Faktor Yang Mempengaruhi. Jakarta: Rineka Cipta.

Slavin, Robert E.S. 2006. Psikologi Pendidikan Teori dan Praktik. Macanan Jaya Cemerlang.

Solso, Robert L., Otto H.M., dan M. Kimberly.M. 2007. Psikologi Kognitif. Erlangga.

Stine, Jean Marie. 2003. Meningkatkan Daya Ingat Anda Dengan Menggunakan Seluruh Otak Anda. Jakarta: Gramedia.

Sudjana. 2005. Metoda Statistika. Bandung: Tarsito Bandung.

Sugiyono. 2011. Metode Penelitian Kuantitatif. Bandung: Alfabeta.

Suprijono, Agus. 2011. Cooperative Learning. Yogyakarta: Pustaka Pelajar.

Surya, Mohammad. 2012. Psikologi Guru Konsep dan Aplikasi. Bandung: Alfabeta.

Syah, Muhibbin. 2013. Psikologi Pendidikan. Bandung: Remaja Rosdakarya.

Uno, Hamzah B. 2010. Profesi Kependidikan. Jakarta: Bumi Aksara.

Usman, Uzer. 2006. Menjadi guru profesional. Bandung: Remaja Rosdakarya. 